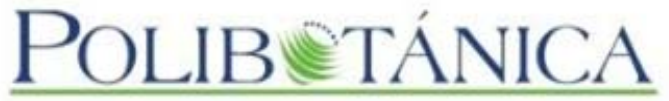

\title{
Polibotánica
}

ISSN electrónico: 2395-9525

polibotanica@gmail.com

Instituto Politécnico Nacional

México

http://www.polibotanica.mx

\section{ADAPTIVE CO-MANAGEMENT OF URBAN FORESTS: MONITORING REFORESTATION PROGRAMS IN MEXICO CITY.}

\section{COGESTIÓN ADAPTATIVA DE BOSQUES URBANOS: MONITOREO DE PROGRAMAS DE REFORESTACIÓN EN LA CIUDAD DE MÉXICO.}

Fernández-Alvarez, R. y R. Fernández-Nava.

ADAPTIVE CO-MANAGEMENT OF URBAN FORESTS: MONITORING REFORESTATION PROGRAMS IN MEXICO CITY.

COGESTIÓN ADAPTATIVA DE BOSQUES URBANOS: MONITOREO DE PROGRAMAS DE REFORESTACIÓN EN LA CIUDAD DE MÉXICO.

\section{POLIBETANICA} Instituto Politécnico Nacional
Núm. 49: 243-258 México. Enero 2020

DOI: $10.18387 /$ polibotanica.49.15

Este es un artículo de acceso abierto bajo la licencia Creative Commons 4.0 Atribución-No Comercial (CC BY-NC 4.0 Internacional). 


\section{ADAPTIVE CO-MANAGEMENT OF URBAN FORESTS: MONITORING REFORESTATION PROGRAMS IN MEXICO CITY}

\section{COGESTIÓN ADAPTATIVA DE BOSQUES URBANOS: MONITOREO DE PROGRAMAS DE REFORESTACIÓN EN LA CIUDAD DE MÉXICO}

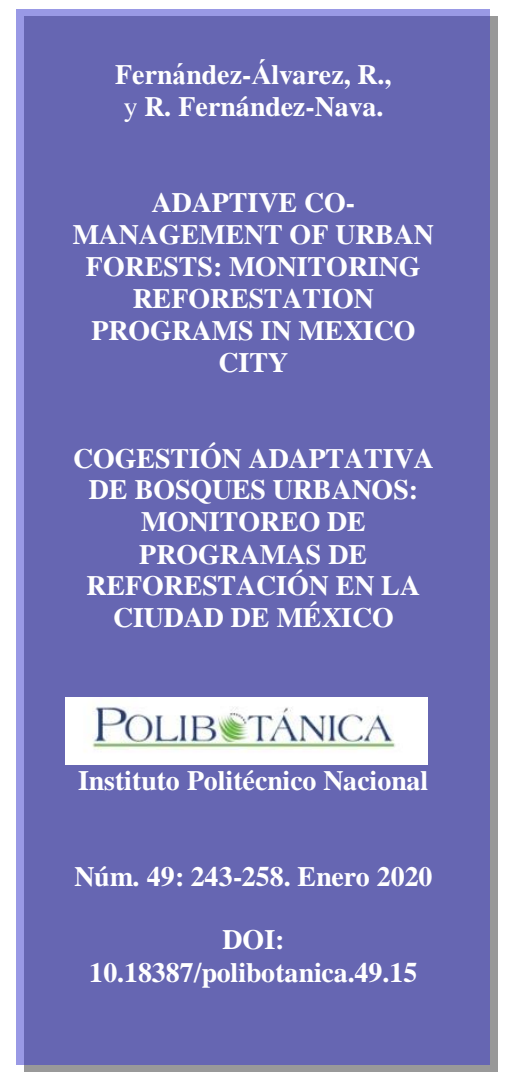

Fernández-Álvarez, R.,

y R. Fernández-Nava.

ADAPTIVE CO-

MANAGEMENT OF URBAN

ORESTS: MONITORING

REFORESTATION

CITY

COGESTIÓN ADAPTATIVA

BOSQUES URBANOS:

MONITOREO DE

PROGRAMAS DE

REFORESTACIÓN EN LA

CIUDAD DE MÉXICO

Instituto Politécnico Naciona

Núm. 49: 243-258. Enero 2020

DOI:

10.18387/polibotanica.49.15

\author{
R. Fernández-Álvarez / rafael.fernandez@ubc.ca \\ Department of Forest Resources Management, Faculty of Forestry, \\ University of British Columbia, 2424 Main Mall, \\ Vancouver, BC V6T 1Z4, Canada. \\ Centro de Investigaciones Económicas, Administrativas y Sociales (CIECAS), \\ Instituto Politécnico Nacional (IPN), \\ Lauro Aguirre 120, Agricultura, 11360 Mexico City, México. \\ R. Fernández-Nava \\ Departamento de Botánica, Escuela Nacional de Ciencias Biológicas, \\ Instituto Politécnico Nacional, México.
}

ABSTRACT: Aiming to maintain or increase the indispensable socio-ecological benefits provided by urban forests, cities of the world have adequate urban forestry to take advantage of new technologies and governmental arrangements. Cooperation among different actors has become a trend to address urban forests' most pressing management issues, such as reforestation monitoring and the creation of tree inventories. This management approach has been conceptualized as adaptive comanagement (ACM) in European and North American cities. Intending to advance the academic efforts to understand ACM, this article presents a spatial and statistical analysis of the distribution of trees monitored in Mexico City. The analysis indicated that the number of urban trees monitored is very low and inequitably distributed in the city; poor areas of the city are not only underserved of green public spaces and trees but have also been neglected in terms of monitoring reforestation programs. The implementation of ACM for environmental management of the urban forest, using the participatory tool of Naturalista, developed by (in Spanish, Comisión Nacional para el Conocimiento y Uso de la Biodiversidad, CONABIO). The tool demonstrated to have much potential in the operationalization of inclusive reforestation programs, particularly in monitoring urban trees recently planted. The implementation of ACM and citizens' science programs are discussed and recommended as a promising urban environmental management approach.

Key words: Urban Reforestation; Environmental Management; Participatory Governance; Urban Forests.

RESUMEN: Con la intención de mantener o incrementar los indispensables beneficios que provén los bosques urbanos, ciudades grandes del mundo han adecuado su gestión forestal urbana para aprovechar nuevas tecnologías y formas de gobierno. La cooperación entre diferentes actores se a convertido en una tendencia para atender los problemas más apremiantes de gestión de busques urbanos, como lo son la reforestación y su monitoreo, así como la creación de inventarios forestales. A esta forma de gestiones le ha conceptualizado como co-gestión adaptativa (CGA) en ciudades europeas y de Norte América. El propósito de este articulo es avanzar en los esfuerzos académicos multidisciplinarios para comprender la (CGA) de bosques urbanos; para eso se presenta un análisis espacial y estadístico de la distribución de árboles monitoreados en la Ciudad de México. El análisis indicó que el número de 
árboles urbanos monitoreados es muy bajo y está distribuido de manera desigual en la ciudad; las áreas pobres de la ciudad no solo están cuentan con menos espacios públicos verdes y árboles, sino que también se han descuidado en términos de monitoreo de los programas de reforestación. La implementación de CGA para la gestión ambiental del bosque urbano también se analizó tomando en cuenta los resultados provistos por la herramienta participativa Naturalista, desarrollada por la Comisión Nacional para el Conocimiento y Uso de la Biodiversidad (CONABIO). La herramienta demostró tener mucho potencial en la operacionalización de programas inclusivos de reforestación, particularmente en el monitoreo de árboles urbanos plantados recientemente. La implementación de GGA y los programas de ciencia ciudadana se discuten y recomiendan como un enfoque prometedor de gestión ambiental urbana.

Palabras clave: Reforestación urbana; Gestión ambiental; Gobernanza participativa; Bosques Urbanos.

\section{INTRODUCTION}

The benefits and importance of urban forests ${ }^{1}$ in cities around the world have been documented extensively; trees within urban areas have a significant influence on water, air and pollution cycles (Livesley, McPherson, \& Calfapietra, 2016), and also provide with sociological, economic, and aesthetic benefits (Garvin \& Brands, 2011; Perino et al., 2014). Therefore, adequate management of the urban forest is indispensable for a sustainable and livable city (Chiesura, 2004).

Urban Forestry_ “ "generally defined as the art, science, and technology of managing trees and forest resources in and around urban community ecosystems" (Konijnendijk et al., 2006; p.2) - has been present in urban settlements in America as early as the 1890s, and the practice keeps evolving to address current problems with new tools. During the XXI century, in North America and Europe, the management of urban trees has centered largely on reforestation and the resulting urban forestry programs (Konijnendijk, 2003; Kroeger et al., 2014; Nilsson et al., 2010). As a general trend, the use of technology has transformed positively the way trees are managed in urban contexts; for instance, the use of satellite remote sensing and Geographic Information Systems (Miller, Hauer, \& Werner, 2015); modern data science has allowed experts and decision-makers to formulate urban forest models and policies based on detailed socio-ecological information collected by academic and governmental institutions, nongovernmental organizations, and even individual citizens.

In addition to new technologies, a key component of urban forest management is the participation of citizens in the formulation and operationalization of public policy directed to trees and other vegetated areas of the city. Traditional top-down decision-making processes have been substituted with a participatory governance approach that spurs citizens and stakeholders to collaborate on addressing socio-ecological problems. Participatory governance, a widely used term in European political science literature (Fung, 2015), predicates upon the citizen's role beyond voter or watchdog; participatory governance includes practices of direct deliberative and operational engagement with pressing issues (Fischer, 2012).

\footnotetext{
${ }^{1}$ The urban forest is defined by the Canadian Urban Forest Network as "the trees, forests, greenspace and related abiotic, biotic and cultural components in and around cities and communities" (in Konijnendijk et al., 2006; p.8). Based on konijnendijk's work(ibid), The Food and agriculture organization of the United Nations (FAO) offers and an alternative definition: The networks or systems comprising all woodlands, groups of trees, and individual trees located in urban and peri-urban areas; they include, therefore, forests, street trees, trees in parks and gardens, and trees in derelict corners. Urban forests are the backbone of the green infrastructure, bridging rural and urban areas and ameliorating a city's environmental footprint(Salbitano, Borelli, Conigliaro, \& Yujuan, 2016).
} 
The participation of diverse non-expert actors is essential for adequate urban forest management due to the fact that it can yield large amounts of data remotely; for example, online tools have been broadly used to generate urban forest inventories and to collect other types of information (see i-tree and other platforms; e.g. Hirabayashi \& Kroll, 2017; Nowak, Maco, \& Binkley, 2018; Pace, Biber, Pretzsch, \& Grote, 2018). Environmental management literature refers to this active interaction of a diverse group of actors towards a common goal as adaptive co-management. Adaptive co-management (ACM) is generally understood as "a process by which institutional arrangements and ecological knowledge are tested and revised in a dynamic, ongoing, self-organized process of trial-and-error'" (Folke et al., 2002, p. 8; in Baird, Plummer, \& Bodin, 2016). It implicates mixed actors cooperating across scales and through institutional and formal/informal channels (horizontally and vertically) to undertake actions and learn through feedback (Armitage et al., 2009).

ACM has been implemented in several cities to improve and expand the participatory monitoring of trees and the urban forest in general (Baird et al., 2016; Pace et al., 2018; Van der Jagt et al., 2019). Mexico City is an illustrative example of ACM applied for monitoring urban trees because of two reasons. First, with the explicit objective to spur civic participation, the Mexican federal government funded Naturalista, a science divulgation online platform administered by the National Commission for Biodiversity Knowledge and Use (in Spanish, Comisión Nacional para el Conocimiento y Uso de la Biodiversidad, CONABIO). Naturalista was originally designed after iNaturalist, a citizen science project and online social network devised to map and share observations of biodiversity across the globe. As of 2018, CONABIO's Naturalista has registered 26637 observations of trees in Mexico City and is rapidly consolidating as a salient and legitimate participatory tool useful for monitoring the urban forest. Secondly, aiming to increase the cooperation among diverse actors, the task of reporting on the progress of reforestation has been officially given to the Environment and Land Management Agency for the Federal District (in Spanish Procuraduría Ambiental y del Ordenamiento Territorial del Distrito Federal, PAOT). The PAOT has been logging information on urban trees in Mexico City since 2013; the "arboreal census" of Mexico City has been conducted with the help of scientific experts and has registered 20122 trees. ACM of the urban forest in Mexico City has been implemented for almost a decade but it is yet to be scrutinized.

This article presents a spatial and statistical analysis of the distribution of trees monitored by both systems of PAOT and Naturalista to determine if and how ACM can be a productive approach for urban forests. Considering the current state of environmental degradation suffered in México City and other super populated cities of the world, it is indispensable to assess institutionalized mechanisms used to manage natural resources in urban contexts.

\title{
Materials And Methods
}

\begin{abstract}
Study site
Mexico City has a total area of $1,485 \mathrm{~km}^{2}(573 \mathrm{sq} . \mathrm{mi})$ and a population of 8.851 million (INEGI, 2010). In addition, the Metropolitan Area of Mexico City (MCMA) comprise 16 boroughs, 59 municipalities of the state of Mexico and 29 municipalities of the state of Hidalgo - the aggregate population is approximately 21.3 million (Delgado, 2012). It is the city with the highest population density in Latin America (Habitat, 2012). Given the massive size of the MCMA and for practical reasons, this research concentrated only in Mexico City and its 16 boroughs. This research used the Mexico City reforestation program of 2016-2018 as a spatial reference for this analysis. That is, to determine were ACM monitoring efforts should be directed.
\end{abstract}

2 The reforestation program was presented and implemented by the administration of governor Miguel Angel Mancera (in office from December 5, 2012 to March 29, 2018). 
According to the official report by the Mexico City Environment Secretariat (in Spanish, Secretaria del Medio Ambiente del Distrito Federal, SEDEMA), the reforestation program processed a total of 6379 trees within nine of sixteen boroughs using a \$50 MXP million $(\sim 260,000$ USD) budget (Table 1). Notice that Iztapalapa, Cuauhtémoc and Alvaro Obregon were significantly favored compared to other boroughs (Map 1). This data provides important information regarding the specific geographical areas of the city were reforestation has been taking place. In the case of Iztapalapa, this high reforestation tendency may respond to the fact that the borough was reported to be significantly underserved with green public space (Fernández-Álvarez, 2017) and urban vegetation in general (Maldonado-Bernabé et al.,2019). In the cases of Miguel Hidalgo, Alvaro Obregon and Cuauhtémoc, these boroughs have been hosting the large majority of green public spaces and urban vegetation in the city (i.e. Chapultepec Forest, Alameda Central Park, Parque Mexico, etc.) and have been historical priorities for the Mexican administrations through the years (Wakild, 2007). It is important to highlight that this research was not limited to analyze the 2016-2018 Reforestation Program, but included data provided by both systems of PAOT and Naturalista for the 16 boroughs of the city.

Table 1. Mexico City Reforestation Program per borough 2016-2018.

Trees planted per year

\begin{tabular}{lrrrrrr}
\cline { 2 - 3 } \multicolumn{1}{c}{ Mexico City Boroughs } & $\mathbf{2 0 1 6}$ & $\mathbf{2 0 1 7}$ & $\mathbf{2 0 1 8}$ & Totals per borough & \% of total reforestation \\
\hline Azcapotzalco & 0 & 0 & 0 & 0 & 0.00 \\
Coyoacán & 19 & 209 & 0 & 228 & 3.57 \\
Cuajimalpa de Morelos & 355 & 250 & 0 & 605 & 9.48 \\
Gustavo A. Madero & 0 & 0 & 0 & 0 & 0.00 \\
Iztacalco & 0 & 0 & 0 & 0 & 0.00 \\
Iztapalapa & 1134 & 792 & 53 & 1979 & 31.02 \\
La Magdalena Contreras & 0 & 0 & 0 & 0 & 0.00 \\
Milpa Alta & 0 & 0 & 0 & 0 & 0.00 \\
Álvaro Obregón & 1497 & 37 & 0 & 1534 & 24.05 \\
Tláhuac & 0 & 324 & 176 & 500 & 7.84 \\
Tlalpan & 33 & 44 & 0 & 77 & 1.21 \\
Xochimilco & 67 & 101 & 0 & 168 & 2.63 \\
Benito Juárez & 0 & 156 & 0 & 156 & 2.45 \\
Cuauhtémoc & 239 & 189 & 96 & 524 & 8.21 \\
Miguel Hidalgo & 175 & 167 & 0 & 342 & 5.36 \\
Venustiano Carranza & 33 & 231 & 2 & 266 & 4.17 \\
Totals & 3552 & 2500 & 327 & 6379 & 100.00
\end{tabular}

Source: adapted from data included in the Programa de Reforestación CDMX 2016-2018 available at https://bit.ly/2CeLOg7 


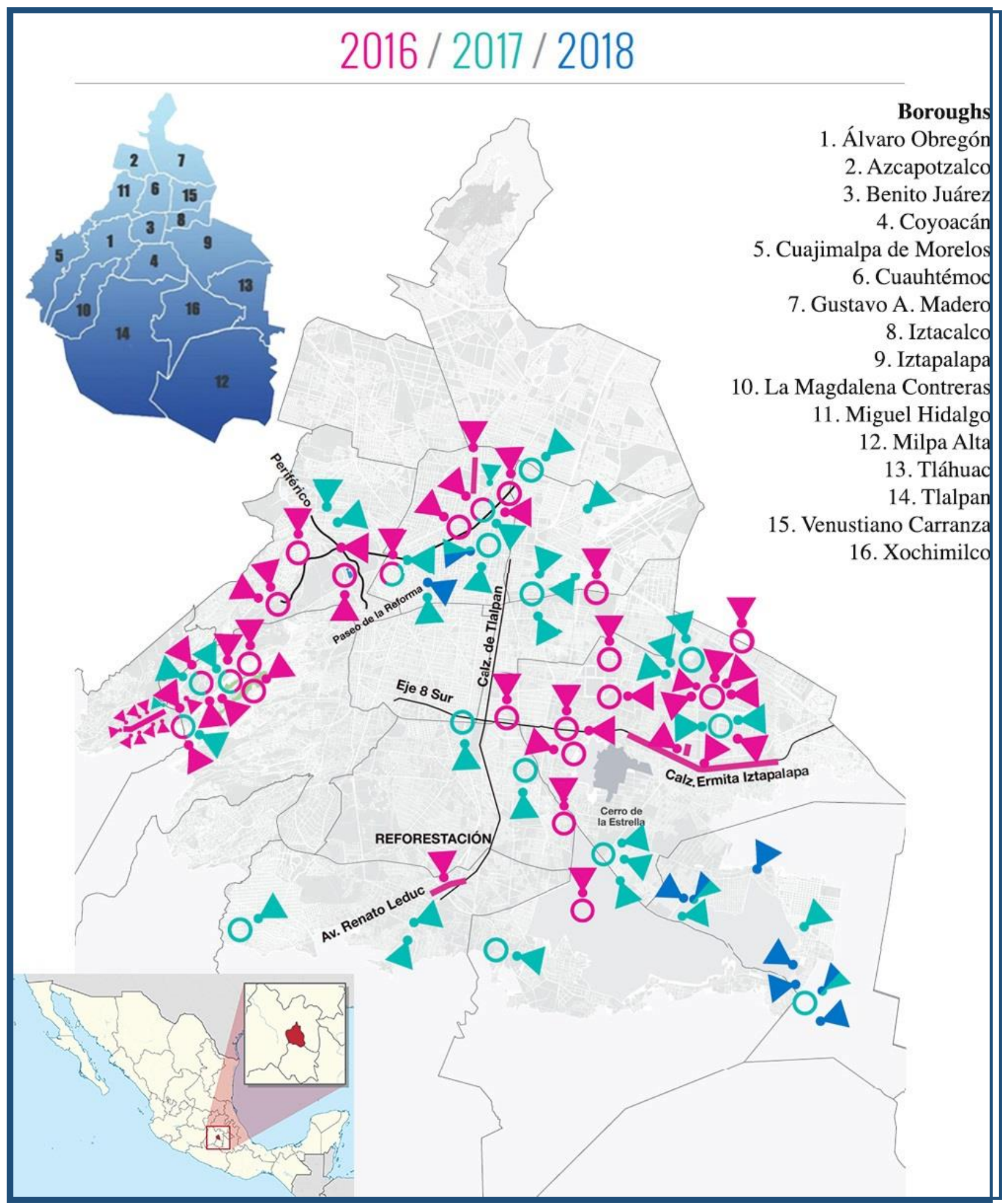

Map 1. Mexico City Reforestation Program sites 2016-2018. Source: adapted from maps included in the Programa de Reforestación CDMX available at https://bit.ly/2CeLOg7 


\begin{abstract}
Methodological Approach
Urban forests have been studied with a suit of varied methods. In the particular case of distribution of urban trees or urban vegetation a combination of statistical and spatial analysis is the academic standard; specifically, geostatistical interpolation has been a widely used tool for green public spaces such as parks and other forms of green public space (Boone et al., 2009; Nesbitt, Meitner, Girling, \& Sheppard, 2019; Yang, Xiao, \& Ye, 2016). Spatial analysis has been used to unveil patterns of concentration in specific areas of a city; classical studies on environmental justice and other sorts of distributional studies have shown that trees are not equitable allocated in the urban space, but rather concentrated on white-affluent areas of cities (see Boone et al., 2009; Oh \& Jeong, 2007; Sister, Wolch, \& Wilson, 2009). The ubiquitous statistical dimension in these studies responds to the fact that most spatial data contains also demographic features useful to determine if there are correlations among gender, age, education level, race or income (e.g. Nesbitt, Meitner, Girling, Sheppard, \& Lu, 2019). For these reasons, the current research applied a spatial distribution analysis coupled with a simple categorical regression calculated from data provided by both the PAOT and Naturalista systems. The spatial distribution analysis was conducted using QGIS 3.6 (Noosa) and its vector analysis tools to count points within census tracts polygons. The regression was calculated using Excel and the graphic was created with the Data Plotly (R plug-in) for QGIS. The spatial distribution analysis presented for this research consisted of identifying concentration patterns of registered trees by PAOT and Naturalista in the 16 boroughs of Mexico City. Furthermore, the spatial concentration of registered trees via Naturalista was compared to the number of green public spaces per census tract, the objective was to recognize discernable concentration patterns for both datasets.
\end{abstract}

\title{
Data collection and analysis
}

As stated earlier, one of the most salient actors in the governance of the urban forest in CDMX is the Attorney's Office for the Territory and Environment of Mexico City (in Spanish Procuraduría Ambiental y del Ordenamiento Territorial, PAOT). The PAOT provides an important compilation of data related to socio-ecological issues, these include reports on green public spaces, land use, environmentally vulnerable areas, and environmental violations. Urban Reforestation Programs have been monitored using the Arboreal Census (in Spanish Censo Arbolado; data compiled since 2013). The arboreal census program conducted by PAOT has been the only institutional effort to account for trees planted in the Mexican capital. PAOT made available 32 information packs with a total of 20123 trees lodged per census tract in the 16 boroughs of $\mathrm{CDMX}^{3}$. The arboreal census included only ecologic data- e.g. species name, height, canopy condition and size, etc. - and geospatial data. The original datasets were very heterogeneous and most of the information packages included were disjointed, mislabeled and contained contradictory information. Nonetheless, census data was rearranged and prepared for analysis purposes ${ }^{4}$.

Moreover, a total of 26637 tree observations ${ }^{5}$ collected via the Naturalista application/platform were provided by the National Commission for Biodiversity Knowledge and Use (in Spanish, Comisión Nacional para el Conocimiento y Uso de la Biodiversidad, CONABIO). Each of these observations registered in the Naturalista system contained geospatial data and the ecological characteristics of reported trees. Naturalista was created as a digital citizen science platform, one of the most used tools in large cities in the world to monitor urban biodiversity.

\footnotetext{
${ }^{3}$ Original data sets can be consulted and downloaded from http://www.paot.mx/micrositios/Atlas Urbano CDMX 2018/files/arbolado.html

${ }^{4}$ Data features such as address, geo-reference and census number were homologated in order to ensure spatial consistency for the analysis. Data related to ecological features such as height, canopy size and overall condition were not used due to mislabeling and considerable differences in the measurements registered throughout all datasets.

${ }^{5}$ Observations in the context of the Naturalista platform refers to the record of a plant or animal logged into the participatory tool system. Each observation represents an item with a data set. For more information about the mechanics of the app go to https://www.naturalista.mx
} 
Citizen science has as its basic principle the integration of the collective capacity to collect data to the formulation of public policies and scientific knowledge; these types of tools are indispensable for participatory governance (Blum, 2016; Jordan, Ballard, \& Phillips, 2012). Naturalista and most citizen science platforms are created and managed by expert scientists who validate the data collected by citizens. Users have at their disposal extensive databases to determine the taxonomy and other ecological features of the species that are registered within Naturalista. If there is any doubt about it, users can ask an expert for help via the application to identify the species observed. It is important to note that the Naturalista geo-locator uses state of the art technology that allows data to be generated through real-time satellite communication with a minimum margin of error. All this serves to make sure the validity of the observations recorded.

The analysis of this data also intended to show concentration patterns of observations in specific areas of the city. The different concentrations of Naturalista observations per census tract were categorized into eleven groups using Natural Breaks (Jenks) ${ }^{6}$ from 1 (representing 0 -3 records) to 11 (representing 1634-4549 records) per census tract. This categorization was used to conduct a simple categorical regression of the observations and green public space (GPS) concentration per census tract. To generate a count of GPS point per census tract, a centroid was calculated for all polygons registered as green public space in data sets provided PAOT.

\section{Results}

The concentration of logged trees by PAOT for the arboreal census shows that there are very few trees in CDMX officially documented for management purposes - a total of 20123 for the entire city (Map 2). Moreover, the concentration of trees monitored is very high in the center and northeast of the city. Yet, the marginal areas of the city such as the borough of Iztapalapa, Azcapotzalco, and Iztacalco have received little to none attention on this matter. However, interestingly, other marginalized boroughs such as Gustavo A. Madero concentrate the largest number of trees lodged during the census. The robust monitoring of trees in the borough of Gustavo A. Madero could respond to the fact that the Aragon Forest, the San Juan de Aragon Zoo and the National Tepeyac Park are located in that borough.

The borough of Iztapalapa located in the south-east area of the city seems to be particularly deficient in terms of institutional monitoring with only 230 trees registered - consider that, as presented in Map 1, this borough has concentrated the largest number of trees from reforestation programs in the past 4 years (a total of 1979 trees, $31 \%$ of the total planted during the program). In sharp contrast monitoring has been concentrating on the borough of Cuauhtémoc in the downtown district of Mexico City - a total of 5060 trees were registered in that borough, yet, it only received 524 new trees during the reforestation.

The spatial analysis of observations registered in Naturalista per census tract and the PAOT arboreal census showed similar patterns; in both cases, the East of the city presented a very low concentration of observations and monitoring, respectively (Map 3). Conversely, the south center of the city concentrates most of the activity related to CONABIO's participatory tool. This pattern could be solely based on the concentration of green public space; people will be much more prone to participate using the application in vegetated areas and discouraged to

\footnotetext{
${ }^{6}$ The Jenks optimization method, also called the Jenks natural breaks classification method (Chen et al., 2013), is one of the data clustering methods designed to determine the best arrangement of values into different classes (Ahmad, 2019). "Natural breaks" are the best way to split up ranges. Best ranges imply the ranges where like areas are grouped together. This method minimizes the variation within each range, so the areas within each range are as close as possible in value to each other.
} 
participate in barren spaces. Such an assumption could only be proved after analyzing the data with a categorical regression model (fig. 1); the analysis shows that $89 \%$ of the variation associated with concentration of observations via Naturalista is predicted by the concentration of GPS. Such a high social response represents a promising resource for participatory governance oriented to adaptive co-management in the particular case of the urban socioecological system of Mexico City. However, this analysis also confirms the steep differences among boroughs in the city in the distribution and also monitoring of trees. In other words, the partial concentration of observations via Naturalista shows that specific marginalized areas of the city remain to be severely underserved of GPS while the recently reforested areas receive little to no institutional monitoring.

\section{DISCUSSION}

The institutional efforts of current and past administrations in Mexico City have resulted in the implementation of progressive policies and programs to modernize urban forestry; adaptive comanagement is an illustrative example. However, based on PAOT's monitoring data, the efforts of monitoring urban trees are quite scant and, considering recent reforestation sites, misplaced. Moreover, the distribution of monitored sites presents a pattern biased against the marginalized areas of the city. Iztapalapa, Iztacalco, Gustavo A. Madero and Azcapotzalco, all boroughs with high levels of marginalization and the lowest number of green public space $\mathrm{m}^{2}$ per habitant, also registered a very low number of observations; this results support the environmental justice postulation that GPS and services related to its management are often biased against poor people (e.g. Bolin, 2013; Boone et al., 2009; Perkins, Heynen, \& Wilson, 2004). In Mexico City, marginalized areas are underserved of trees and lack proper supervision of reforested sites. Furthermore, the high levels of institutional monitoring in the borough of Cuauhtémoc can also be explained because of the concentration of historical green public spaces in the area such as the Alameda Central Park, and the main (forested) avenue of Mexico City, Reforma. This area of the city also has a very high touristic value, important architectural landmarks and the old neighborhood of Condesa are located in this borough. In a sense, trees have been part of the face of Mexico City to tourists since the city was originally built, hence, monitoring this "public to the world areas" has always been a priority (Wakild, 2007). This lack of appropriate monitoring of reforestation projects by decentralized organizations could indicate that the Adaptive Co-Management (ACM) framework or its operationalization is not yielding productive results. Further research on institutionalized monitoring programs for urban trees in the city should provide additional information on trends through time; however, current data indicates that there is a deficit of tree monitoring in general and particularly accentuated in marginalized areas of the city. In this context, adaptive co-governance and other forms of participatory governance seem to be promising approaches for citizens to start addressing the lack of monitoring pressing issues Fung (2015) such as distribution of trees in all areas of the city.

Representative samplings of Mexico City's urban forest have been conducted since the decade of the 1990s (Chacalo, Aldama, \& Grabinsky, 1994; Meza, 1992), however, the majority of studies have been centered on green public spaces and vegetation cover in relation to distribution, ecological and socio-demographic characteristics, management and planning (Checa-Artasu, 2016; Flores Xolocotz \& González-Guillén, 2012; Flores Xolocotzi, GonzálezGuillén, \& de los Santos-Posadas, 2010; Meza Aguilar, 2015; Robles, 2014). The urban forests of Mexico City has been studied with a wide variety of approaches and methodological tools but inventories of Mexico City's trees are scant relative to modern analysis technics using remote sensing tools and images collected via satellites. In addition, until Naturalista was available for the citizens, the collection data regarding trees (tree inventory) were exclusively conducted by PAOT. The data provided by Naturalista provides a new approach to monitor and analyze our urban forest and it should be explored further. 


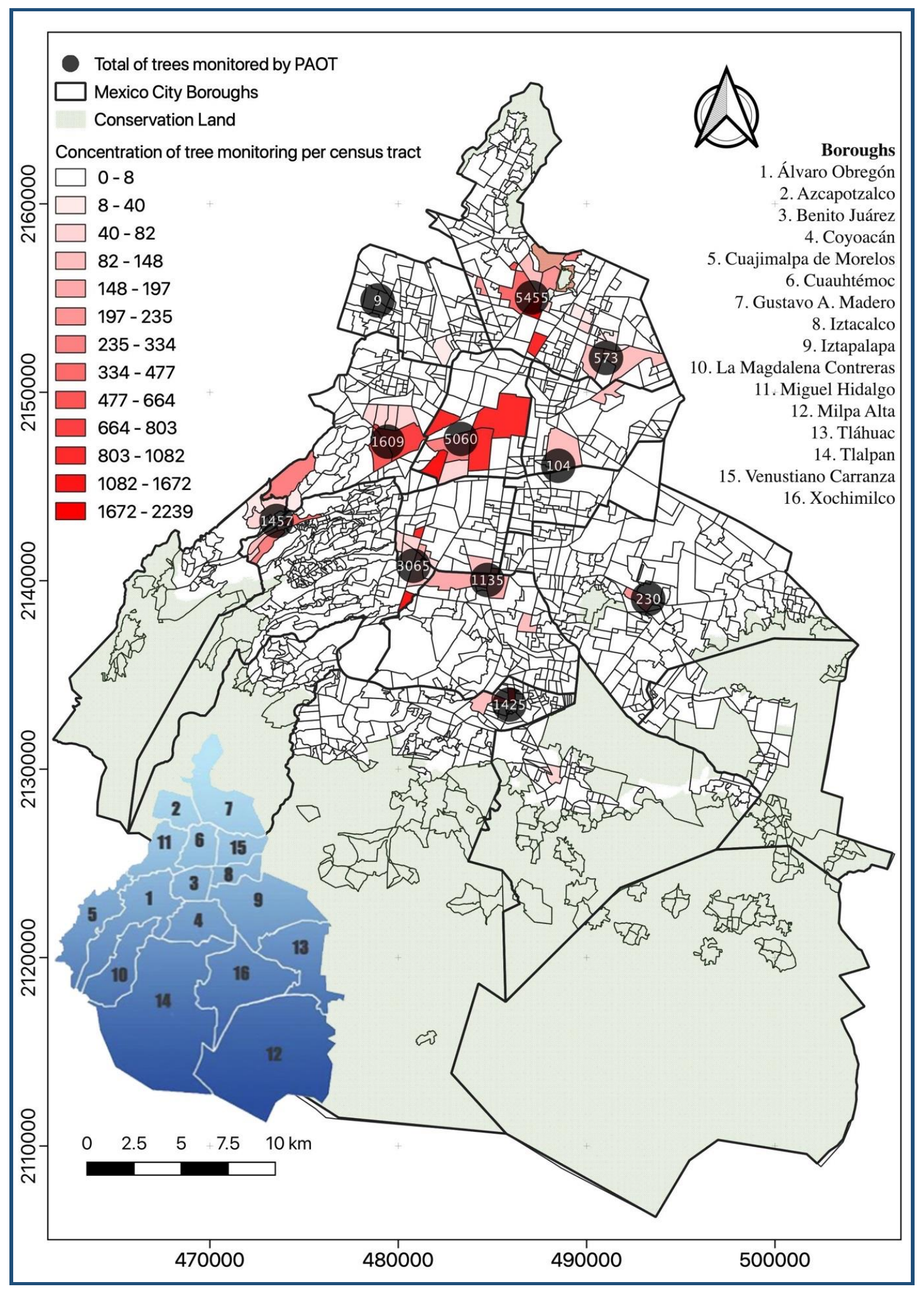

Map 2. PAOT arboreal census distribution in Mexico City (2013-2019). 


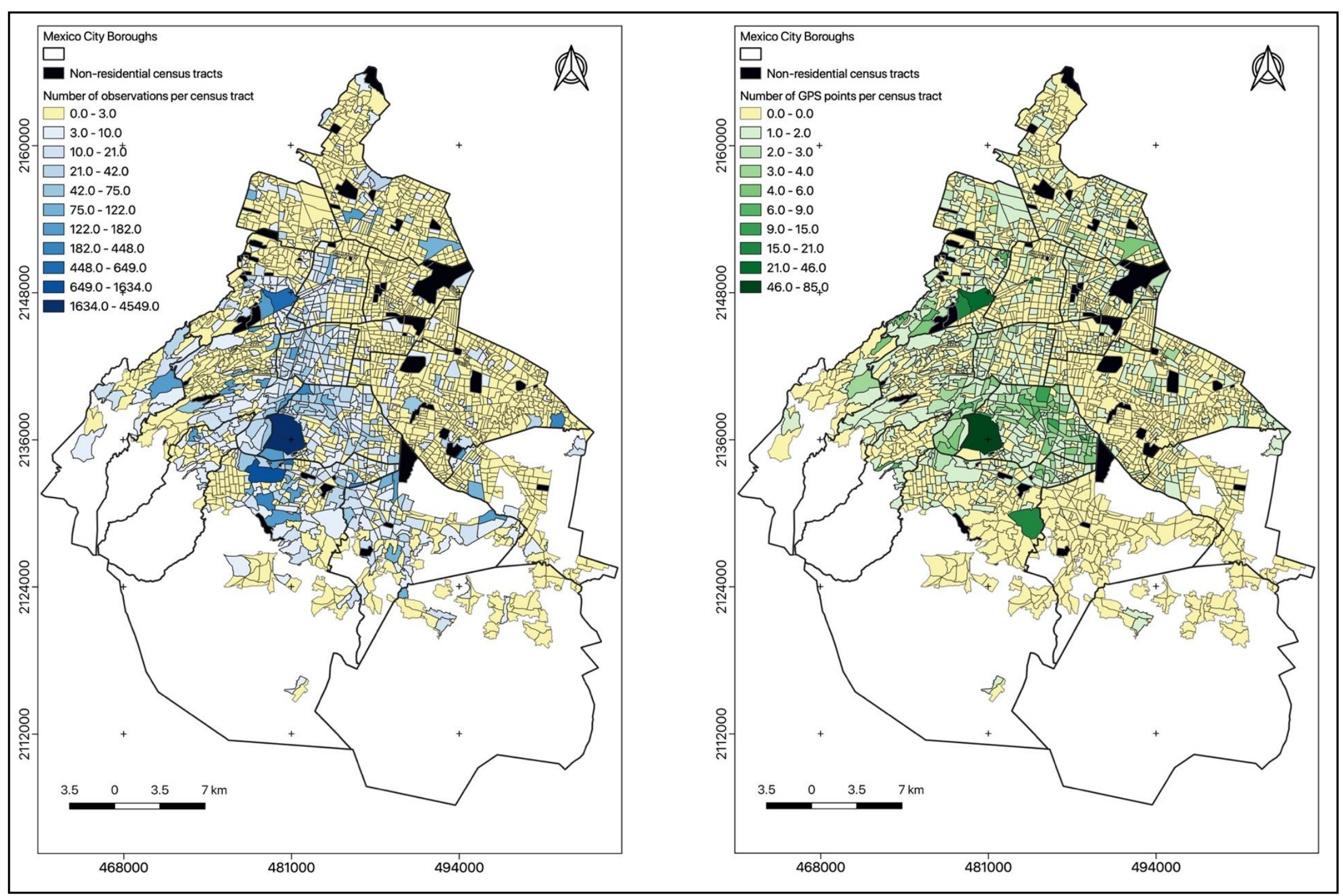

Map 3. Comparison of observations via Naturalista (coded blue) and green public spaces (coded green) concentration per census tract. 


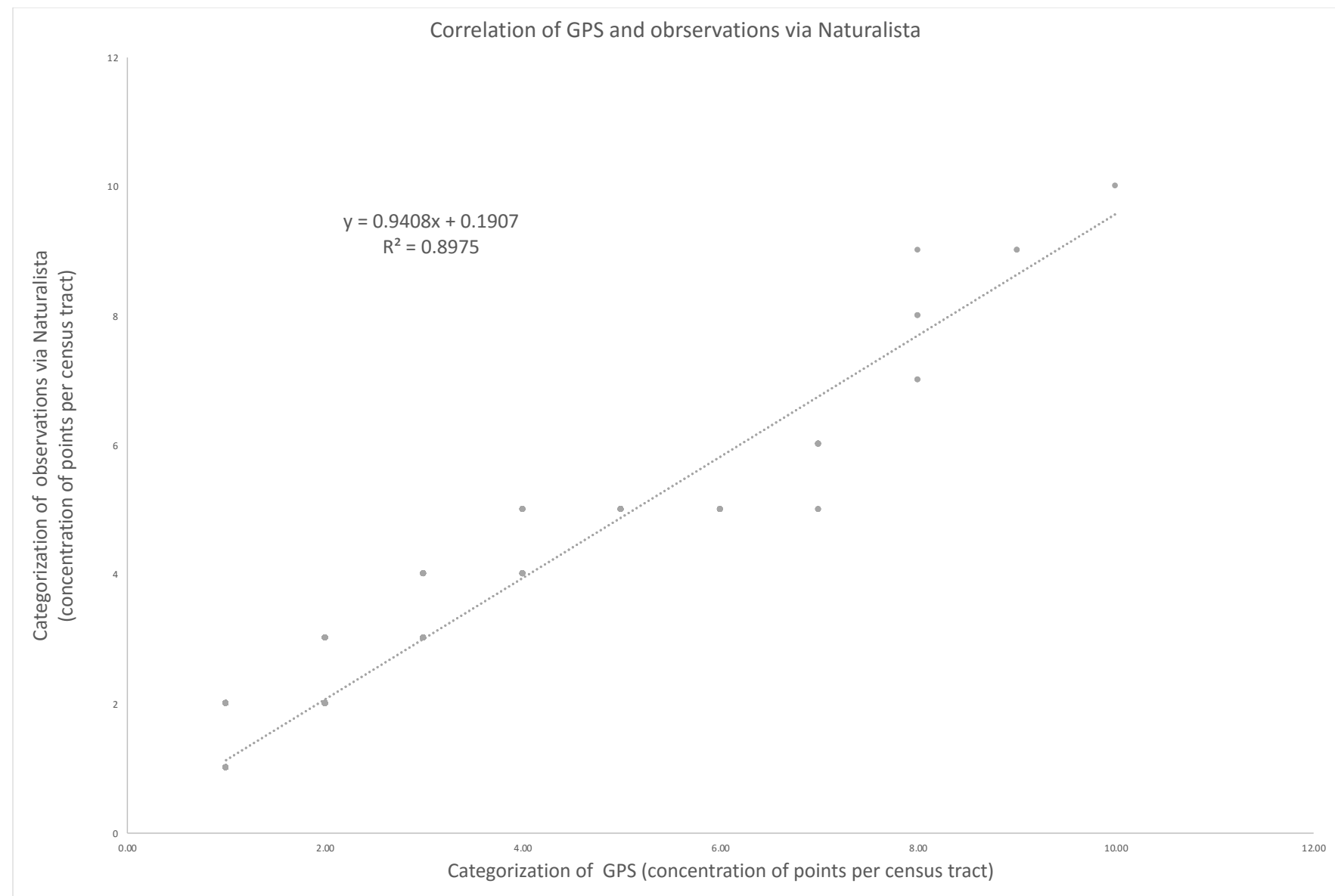

Fig. 1. Correlation of GPS and Naturalista observations.

Interestingly enough, while comparing the efforts of reforestations in large cities of the world, the figures of Mexico City are significantly low. For example, Yao et al. (2019) reported that in the city of Beijing, China, the reforestation strategy by the government involved 50 million new urban trees. Another example can be found in New York City, USA; McPhearson et al. (2017) reported that the reforestation project for the American city was of at least 1 million new urban trees only for the year of 2016. In Mexico City, a two-year reforestation program accounted for less than 10,000 new urban trees. The disparities are considerable and further studies should investigate the reasons why there is no more investment in the reforestation of Mexico City.

The current distribution of reforestation sites, monitoring and civic participation in marginalized boroughs is a clear pattern in Mexico City borough of Iztapalapa is particularly low even though presented the highest number of trees planted during the period analyzed; however, it also presented the lowest concentration of both institutional and civic monitoring.

The inequitable distribution of reforestation sites, monitoring levels and civic participation in the 16 boroughs of Mexico City may be explained as a failure in the institutional arrangements guiding the arboreal census in the city. The PAOT, responsible for monitoring urban reforestation programs, is already capable to collect and process large amounts of data related to urban trees; this fact reveals that adaptive co-management is productive. However, PAOT's 
work should be conducted using equity guidelines to avoid over-monitoring and to assure the punctual assessment of recently reforested areas.

Furthermore, the Naturalista software proved to be a promising participatory tool useful to collect data while enabling citizens to be directly involved with the management of the urban forest. Urban forestry has been greatly beneficiated from citizens' science programs and participatory tools (Su, 2019; Wolf \& Kruger, 2010). Considering the current availability of technology devised to engage people in science and management, involving citizens further should be an objective to be pursued by governments in Mexico City and other large cities of the country.

It is essential to call attention to the fact that social and cultural aspects of trees such (e.g. perceived purpose, use regularity, aesthetic value, cultural value, etc.) are not included in PAOT's arboreal census. Based on the urban forestry literature, for the adequate management of CDMX's urban forest, it is necessary to account for as much as possible of its socioecological dimensions. The current arboreal census should be complemented with a section that further explores the relation of Mexico City residents and their urban trees.

\section{CONCLUSIONS}

A spatial and statistical analysis of the distribution of trees monitored by PAOT was presented to scrutinize the Reforestation Program of Mexico City (2016-2018) in the context of adaptive co-management (ACM). The analysis indicated that the number of urban trees monitored is very low and inequitably distributed in the city. Boroughs like Iztapalapa, recipient of $31 \%$ of the total new trees planted during the period studied, received significantly less monitoring activity compared with other boroughs of the city. In the case of the Mexican capital, ACM was implemented for environmental management, specifically for the urban forest, using the participatory tool of Naturalista operated by CONABIO. The tool demonstrated to have much potential in the operationalization of inclusive reforestation programs considering that, for example, the Naturalista platform collected information from 26637 trees whereas the PAOT was capable to register information from 20122 trees. Data showed that citizens' participation in monitoring the urban environment has been increasing and could represent an important source of information useful to generate adequate urban forestry practices.

\section{ACKNOWLEDGMENTS}

The authors thank Engr. Abraham Alvarez Bustos for his recommendations on the statistical analysis. Funding: This work was funded by the Mexican federal government via CONACYT (postdoctoral fellowship number 35840).

\section{BIBLIOGRAPHY}

Ahmad, R. (2019, August 5). Jenks Natural Breaks-Best range finder algorithm. Retrieved November 11, 2019, from Medium website: https://medium.com/analyticsvidhya/jenks-natural-breaks-best-range-finder-algorithm-8d1907192051

Armitage, D. R., Plummer, R., Berkes, F., Arthur, R. I., Charles, A. T., Davidson-Hunt, I. J., ... Marschke, M. (2009). Adaptive co-management for social-ecological complexity. Frontiers in Ecology and the Environment, 7(2), 95-102. https://doi.org/10.1890/070089 
Baird, J., Plummer, R., \& Bodin, Ö. (2016). Collaborative governance for climate change adaptation in Canada: Experimenting with adaptive co-management. Regional Environmental Change, 16(3), 747-758. https://doi.org/10.1007/s10113-015-0790-5

Blum, J. (Ed.). (2016). Urban Forests: Ecosystem Services and Management. https://doi.org/10.1201/b21179

Bolin, B., Barreto, J. D., Hegmon, M., Meierotto, L., \& York, A. (2013). Double Exposure in the Sunbelt: The Sociospatial Distribution of Vulnerability in Phoenix, Arizona. In C. G. Boone \& M. Fragkias (Eds.), Urbanization and Sustainability (pp. 159-178). Retrieved from http://link.springer.com/chapter/10.1007/978-94-007-5666-3_10

Boone, C. G., Buckley, G. L., Grove, J. M., \& Sister, C. (2009). Parks and people: An environmental justice inquiry in Baltimore, Maryland. Annals of the Association of American Geographers, 99(4), 767-787.

Chacalo, A., Aldama, A., \& Grabinsky, J. (1994). STREET TREE INVENTORY IN MEXICO CITY. 5.

Checa-Artasu, M. M. (2016). Las áreas verdes en la ciudad de México. 22.

Chen, J., Yang, S. T., Li, H. W., Zhang, B., \& Lv, J. R. (2013). Research on Geographical Environment Unit Division Based on the Method of Natural Breaks (Jenks). ISPRS International Archives of the Photogrammetry, Remote Sensing and Spatial Information Sciences, XL-4/W3, 47-50. https://doi.org/10.5194/isprsarchives-XL-4W3-47-2013

Chiesura, A. (2004). The role of urban parks for the sustainable city. Landscape and Urban Planning, 68(1), 129-138. https://doi.org/10.1016/j.landurbplan.2003.08.003

Delgado, M. (2012). Water, Energy and Food Security in Mexico City. In K. OttoZimmermann (Ed.), Resilient Cities 2 (pp. 105-111). Retrieved from http://link.springer.com/chapter/10.1007/978-94-007-4223-9_11

Fernández-Álvarez, R. (2017). Inequitable distribution of green public space in the Mexico City: An environmental injustice case. Economía, Sociedad y Territorio, 17(54), 399428. https://doi.org/10.22136/est002017697

Fischer, F. (2012). Participatory Governance: From Theory To Practice. The Oxford Handbook of Governance. https://doi.org/10.1093/oxfordhb/9780199560530.013.0032

Flores Xolocotz, R., \& González-Guillén, M. de J. (2012). PLANIFICACIÓ N DE SISTEMAS DE Á REAS VERDES Y PARQUES PÚ BLICOS. Revista Mexicana de Ciencias Forestales, $1(1)$. Retrieved from http://www.revistasinifap.org.mx/index.php/Forestales/article/view/222

Flores Xolocotzi, R., González-Guillén, M. de J., \& de los Santos-Posadas, H. M. (2010). Valoración económica del servicio recreativo del parque Hundido de la Ciudad de México. Región y Sociedad, 22(47), 123-144.

Folke, C., Carpenter, S., Elmqvist, T., Gunderson, L., Holling, C. S., \& Walker, B. (2002). Resilience and sustainable development: Building adaptive capacity in a world of transformations. AMBIO: A Journal of the Human Environment, 31(5), 437-441.

Fung, A. (2015). Putting the Public Back into Governance: The Challenges of Citizen Participation and Its Future. Public Administration Review, 75(4), 513-522. https://doi.org/10.1111/puar.12361

Garvin, A., \& Brands, R. (2011). Public parks: The key to livable communities. New York: W.W. Norton \& Co.

Habitat, O. N. U. (2012). Estado de las ciudades de América Latina y el Caribe 2012. Rumbo a una nueva transición urbana. UN Habitat: Nairobi.

Hirabayashi, S., \& Kroll, C. N. (2017). Single imputation method of missing air quality data for i-tree eco analyses in the conterminous united states. Retrieved January.

INEGI, 2010, XIII Censo de Población y Vivienda 2010. Resultados Definitivos, Instituto Nacional de Estadística y Geografía (INEGI), Internet, recuperado de: www.inegi.org.mx [ Links ]

Jordan, R. C., Ballard, H. L., \& Phillips, T. B. (2012). Key issues and new approaches for evaluating citizen-science learning outcomes. Frontiers in Ecology and the Environment, 10(6), 307-309. https://doi.org/10.1890/110280 
Konijnendijk, C. C. (2003). A decade of urban forestry in Europe. Forest Policy and Economics, 5(2), 173-186.

Konijnendijk, C. C., Ricard, R. M., Kenney, A., \& Randrup, T. B. (2006). Defining urban forestry-A comparative perspective of North America and Europe. Urban Forestry \& Urban Greening, 4(3-4), 93-103.

Kroeger, T., Escobedo, F. J., Hernandez, J. L., Varela, S., Delphin, S., Fisher, J. R., \& Waldron, J. (2014). Reforestation as a novel abatement and compliance measure for ground-level ozone. Proceedings of the National Academy of Sciences, 111(40), E4204-E4213.

Livesley, S. J., McPherson, E. G., \& Calfapietra, C. (2016). The Urban Forest and Ecosystem Services: Impacts on Urban Water, Heat, and Pollution Cycles at the Tree, Street, and City Scale. Journal of Environmental Quality, 45(1), 119-124. https://doi.org/10.2134/jeq2015.11.0567

Maldonado-Bernabé, G., Chacalo-Hilu, A., Nava-Bolaños, I., Meza-Paredes, R. M., \& Zaragoza-Hernández, A. Y. (2019). Cambios en la superficie de áreas verdes de la Ciudad de México entre 1990-2015. POLIBOTANICA, O(48). https://doi.org/10.18387/polibotanica.48.15

McPhearson, P. T., Feller, M., Felson, A., Karty, R., Lu, J. W., Palmer, M. I., \& Wenskus, T. (2017). Assessing the effects of the urban forest restoration effort of MillionTreesNYC on the structure and functioning of New York City ecosystems. Urban Forests: Ecosystem Services and Management, 265.

Meza Aguilar, M. del C. (2015). Los árboles de la Ciudad de México. Guardianes de su imagen y calidad ambiental. Bitácora arquitectura, (31), 96. https://doi.org/10.22201/fa.14058901p.2015.31.56652

Meza, H. M. B. (1992). CURRENT SITUATION OF THE URBAN FOREST IN MEXICO CITY. 5.

Miller, R. W., Hauer, R. J., \& Werner, L. P. (2015). Urban Forestry: Planning and Managing Urban Greenspaces, Third Edition. Waveland Press.

Nesbitt, L., Meitner, M. J., Girling, C., Sheppard, S. R., \& Lu, Y. (2019). Who has access to urban vegetation? A spatial analysis of distributional green equity in 10 US cities. Landscape and Urban Planning, 181, 51-79. https://doi.org/10.1016/j.landurbplan.2018.08.007

Nilsson, U., Luoranen, J., Kolström, T., Örlander, G., \& Puttonen, P. (2010). Reforestation with planting in northern Europe. Scandinavian Journal of Forest Research, 25(4), 283-294.

Nowak, D. J., Maco, S., \& Binkley, M. (2018). i-Tree: Global tools to assess tree benefits and risks to improve forest management. Arboricultural Consultant. 51 (4): 10-13., 51(4), 10-13.

Oh, K., \& Jeong, S. (2007). Assessing the spatial distribution of urban parks using GIS. Landscape and Urban Planning, 82(1-2), 25-32. https://doi.org/10.1016/j.landurbplan.2007.01.014

Pace, R., Biber, P., Pretzsch, H., \& Grote, R. (2018). Modeling ecosystem services for park trees: Sensitivity of i-tree eco simulations to light exposure and tree species classification. Forests, 9(2), 89.

Perino, G., Andrews, B., Kontoleon, A., \& Bateman, I. (2014). The Value of Urban Green Space in Britain: A Methodological Framework for Spatially Referenced Benefit Transfer. Environmental and Resource Economics, 57(2), 251-272. https://doi.org/10.1007/s10640-013-9665-8

Perkins, H. A., Heynen, N., \& Wilson, J. (2004). Inequitable access to urban reforestation: The impact of urban political economy on housing tenure and urban forests. Cities, 21(4), 291-299. https://doi.org/10.1016/j.cities.2004.04.002

Robles, E. H. (2014). El manejo de áreas verdes en la Ciudad de México y Pekín: La búsqueda de la sustentabilidad en grandes ciudades. 9. 
Recibido:

15/octubre/2019

Aceptado:

29/noviembre/2019
Salbitano, F., Borelli, S., Conigliaro, M., \& Yujuan, C. (2016). Guidelines on urban and periurban forestry. FAO Forestry Paper (FAO) Eng No. 178. Retrieved from http://agris.fao.org/agris-search/search.do?recordID=XF2017001603

Sister, C., Wolch, J., \& Wilson, J. (2009). Got green? Addressing environmental justice in park provision. GeoJournal, 75(3), 229-248. https://doi.org/10.1007/s10708-009-9303-8

Su, Y.-T. (2019). The roles of experts in forest-related participatory processes in Europe.

van der Jagt, A. P. N., Smith, M., Ambrose-Oji, B., Konijnendijk, C. C., Giannico, V., Haase, D., ... Cvejić, R. (2019). Co-creating urban green infrastructure connecting people and nature: A guiding framework and approach. Journal of Environmental Management, 233, 757-767. https://doi.org/10.1016/j.jenvman.2018.09.083

Wakild, E. (2007). Naturalizing Modernity: Urban Parks, Public Gardens and Drainage Projects in Porfirian Mexico City. Mexican Studies/Estudios Mexicanos, 23(1), 101123. https://doi.org/10.1525/msem.2007.23.1.101

Wolf, K. L., \& Kruger, L. E. (2010). Urban Forestry Research Needs: A Participatory Assessment Process. Journal of Forestry, 6.

Yang, P., Xiao, Z.-N., \& Ye, M.-S. (2016). Cooling effect of urban parks and their relationship with urban heat islands. Atmospheric and Oceanic Science Letters, 9(4), 298-305. https://doi.org/10.1080/16742834.2016.1191316

Yao, N., Konijnendijk van den Bosch, C. C., Yang, J., Devisscher, T., Wirtz, Z., Jia, L., ... Ma, L. (2019). Beijing's 50 million new urban trees: Strategic governance for large-scale urban afforestation. Urban Forestry \& Urban Greening, 44, 126392. https://doi.org/10.1016/j.ufug.2019.126392 